\title{
PROMOSI CITRA DESTINASI DAN KUALITAS PRODUK: KEUNGGULAN BERSAING UMKM KAMPUNG WISATA BISNIS TEGALWARU BOGOR
}

\author{
Deden Kurniawan $^{1 *}$, Yudo Rizky Ramadhan ${ }^{1}$, Fauzi Nur Iman ${ }^{1}$ \\ ${ }^{1}$ Program Studi Ekonomi dan Bisnis, Universitas Mercu Buana \\ Email: deden.kurniawan@mercubuana.ac.id, yudorizky712@gmail.com, \\ fauzi@mercubuana.ac.id
}

*Korespondensi: deden.kurniawan@mercubuana.ac.id

(Submission 03-09-2021, Revissions 09-09-2021, Accepted 09-09-2021)

\begin{abstract}
The progress of tourism will affect the promotion of UMKM and the impact of the existence of UMKM will be more developed, tourism will affect the emergence of new entrepreneurs in various sectors that support tourism activities. Tourism development has an impact in the form of a stimulus for the development of UMKM around tourist areas, so that tourism has a positive impact on tourism business actors, especially for the economy of the surrounding community. This study aims to discuss what factors influence the competitive advantage of Tegalwaru UMKM. The independent variables obtained from the preliminary survey results are promotion, destination image, and product quality. This study uses SEM data analysis techniques and data processing using PLS version 3.0. The population is UMKM located in Tegalwaru, Bogor. With a sample size of 160 respondents. The sampling technique used simple random sampling. By using a quantitative method approach. The results of this study indicate that promotion has a significant positive effect on competitive advantage, destination image has a significant positive effect on competitive advantage, and product quality has a positive and significant effect on competitive advantage.
\end{abstract}

Keywords: promotion, destination image, product quality, competitive advantage and $U M K M$.

\begin{abstract}
Abstrak
Kemajuan pariwisata akan berpengaruh terhadap terangkatnya UMKM dan dampaknya keberadaan UMKM akan lebih berkembang, pariwisata mempengaruhi munculnya pengusaha baru di berbagai sektor pendukung kegiatan wisata. Pengembangan pariwisata memberikan dampak berupa stimulus untuk perkembangan UMKM di sekitar kawasan wisata tersebut, sehingga pariwisata berdampak positif oleh para pelaku usaha jasa pariwisata utamanya untuk ekonomi lokal. Penelitian ini bertujuan untuk membahas mengenai faktor apa saja yang mempengaruhi keunggulan bersaing UMKM Tegalwaru. Variabel independen yang didapatkan dari hasil survei pendahuluan adalah promosi, citra destinasi, dan kualitas produk. Penelitian ini menggunakan teknik analisis data SEM dan
\end{abstract}


pengolahan data menggunakan PLS versi 3.0. Populasinya adalah UMKM yang berwilayah di Tegalwaru, Bogor. Dengan sampel 160 responden. Teknik pengambilan sampel menggunakan simple random sampling. Dengan menggunakan pendekatan metode kuantitatif. Hasil penelitian ini menunjukan bahwa promosi berpengaruh positif signifikan terhadap keunggulan bersaing, citra destinasi berpengaruh positif signifikan terhadap keunggulan bersaing, serta kualitas produk berpengaruh positif dan signifikan terhadap keunggulan bersaing.

Kata Kunci: promosi, citra destinasi, kualitas, keunggulan bersaing dan UMKM.

\section{PENDAHULUAN}

Indonesia dengan kekayaan sumber daya alamnya memiliki potensi besar untuk mengembangkan berbagai industri pariwisata sebagai komponen penting dalam pariwisata Indonesia. Banyaknya wisatawan yang berkunjung ke Indonesia, tidak lepas dari gencarnya pemasaran pariwisata yang dilakukan oleh berbagai pihak. Pemasaran pariwisata yang dilakukan melalui berbagai media, merupakan suatu upaya mengidentifikasi kebutuhan dan keinginan wisatawan, serta menawarkan produk wisata sesuai keinginan dan kebutuhan wisatawan menurut (Utama, 2016). Pasal 1 ayat (5) Undang-Undang Nomor 10 Tahun 2009 tentang Kepariwisataan menyatakan bahwa Daya Tarik Wisata adalah segala sesuatu yang memiliki keunikan, keindahan, dan nilai yang berupa keanekaragaman kekayaan alam, budaya, dan hasil buatan manusia yang menjadi sasaran atau tujuan kunjungan bagi suatu wisatawan.

Potensi pariwisata juga dapat meningkatkan kontribusi devisa, menjadi pengungkit perekenomian regional, dan membuka lapangan pekerjaan masyarakat. Perkembangan pariwisata juga menjadi stimulus dan mempercepat pertumbuhan ekonomi karena dapat meningkatkan sisi permintaan, baik konsumsi maupun investasi yang akan menimbulkan kegiatan produksi barang dan jasa. Data proyeksi penerimaan dari sektor utama dalam perekonomian Indonesia menunjukan sumbangan devisa dari pariwisata selalu meningkat seiring tahun berjalan (Sipayung, 2013).

Sektor pariwisata juga menjadi penggerak dalam pengembangan Usaha Mikro Kecil dan Menengah (UMKM) untuk meningkatkan daya tahan ekonomi nasional. Pengembangan UMKM dapat menjadi katup pengaman dari terjadinya krisis moneter. Dilihat dari manfaat dan perannya, UMKM dan Pariwisata memiliki keberadaan saling melengkapi pada perekonomian sehingga menjadi wadah bekerja yang baik, mampu bertahan, meningkatkan kualitas hidup masyarakat, dan memberikan dampak secara global pada perekonomiaan nasional (Anggraeni et al., 2013). Kemajuan pariwisata juga berdampak pada munculnya pengusaha baru di berbagai sektor pendukung kegiatan wisata, memberikan stimulus untuk perkembangan UMKM di sekitar kawasan wisata tersebut, serta para pelaku usaha jasa pariwisata untuk ekonomi lokal.

Kotler dan Armstrong (2012) menyatakan bahwa promosi merupakan kegiatan mengomunikasikan manfaat dari sebuah produk dan membujuk target 
konsumen untuk membeli produk tersebut. Salah satu yang menunjang keberhasilan sebuah penjualan adalah berbagai bentuk promosi. Promosi digunakan oleh perusahaan untuk memperkenalkan produknya kepada masyarakat agar tercapai penjualannya dan kesadaran terhadap suatu produk perusahaan lebih meningkat. Promosi merupakan hal terpenting dalam memasarkan produk sehingga konsumen akan tertarik melakukan pembelian produk tersebut, sehingga promosi dirancang semenarik mungkin dan informasi yang disampaikan dapat dimengerti dengan mudah oleh masyarakat.

Suatu citra tidak terbentuk dengan sendirinya, melainkan dengan persepsi seseorang terhadap suatu objek. Kotler (1994) dalam Utama (2016) menyatakan bahwa citra adalah sejumlah keyakinan, ide dan kesan yang dipegang oleh seseorang tentang sebuah objek. Sedangkan citra yang terdapat pada suatu destinasi wisata dikenal dengan istilah citra destinasi. Caldwell dan Coshall (2002) menyebut citra destinasi sebagai kesan wisatawan terhadap destinasi wisata.

Echtner dan Ritchie (2003) menyatakan bahwa terdapat dua hal penting dalam proses pembentukan citra destinasi, yaitu: pertama, seseorang dapat memiliki citra destinasi walaupun belum pernah mengunjungi objek tersebut karena destinasi tersebut sudah terkenal melalui berbagai media informasi yang diterimanya, dan; kedua, mengalami perubahan pada citra destinasi sebelumnya dan setelah seseorang melakukan kunjungan ke suatu destinasi. Coban (2012) menyebutkan bahwa citra destinasi juga terdiri dari hasil penilaian rasional atau citra kognitif (cognitive image) dan penilaian emosional atau citra afektif (affective image) dari destinasi itu sendiri.

Namun demikian, Tjiptono (2012) menyatakan bahwa kualitas produk dan layanan, kepuasan pelanggan, dan loyalitas pelanggan merupakan tiga elemen kunci yang dapat menentukan kesuksesan implementasi konsep pemasaran. Ketiga aspek ini telah menjadi bagian dari sebuah organisasi, baik organisasi laba maupun nirlaba. Upaya mengukur dan mengelola ketiga elemen ini terus-menerus dikembangkan, terutama sejak dekade 1980-an. Menurut Tjiptono (2012), kualitas produk adalah semua yang bisa ditawarkan dipasar untuk mendapatkan suatu perhatian, permintaan, dan konsumsi yang dapat memenuhi suatu keinginan atau kebutuhan. Kualitas produk merupakan hasil dari produksi yang diberikan kepada konsumen untuk dimanfaatkan konsumen dalam memenuhi suatu kebutuhannya.

Sunyoto (2015) menyatakan bahwa suatu perusahaan harus memiliki kemampuan untuk membedakan produk yang dihasilkan dalam persaingan untuk mendapatkan keunggulan bersaing. Putu dan Ketut (2017) merumuskan keunggulan bersaing sebagai nilai pada sebuah perusahaan dari hasil penerapan strateginya sehingga perusahaan tersebut memiliki nilai lebih dibanding pesaingnya. Keunggulan bersaing itu sendiri merupakan salah satu faktor penentu dari sukses perusahaan yang diperlukan agar tetap bertahan, atau menjadi lebih kompetitif.

Osmanovic et al (2010) menyebutkan bahwa manajemen pariwisata merupakan suatu konsep yang memuat serangkaian tindakan yang sudah terkoordinasi dari semua stakeholder untuk menghasilkan berbagai bentuk 
pengalaman berwisata dengan cakupan kerja yang sangat luas, mulai dari perencanaan dan pengembangan, pemasaran dan layanan informasi, serta manajemen pengunjung, dan sumber daya pariwisata. Wardoyo dan Veronica, 2013) menyatakan bahwa pengelolaan adalah suatu kegiatan yang bertumpu pada serangkaian bentuk perencanaan, pengorganisasian, penggerakan dan pengawasan untuk mencapai suatu tujuan yang hendak dicapai.

Penelitian terdahulu yang dilakukan Rani (2019) menyatakan, agar dapat bersaing dengan perusahaan lain, perusahaan harus memiliki citra perusahaan yang baik. Citra perusahaan dapat dijadikan sebagai strategi dalam mencapai keunggulan bersaing. Oleh sebab itu, perlu meningkatkan citra perusahaan untuk mencapai keunggulan bersaing dengan cara mempertahankan citra perusahaannya kepada konsumennya. Ada hubungan antara variabel promosi dengan keunggulan bersaing, yang berpengaruh positif dan signifikan terhadap keunggulan bersaing untuk meningkatkan penjualan perusahaan.

Penelitian tersebut juga menyatakan bahwa kualitas produk berpengaruh positif dan signifikan terhadap keunggulan bersaing untuk mempertahankan elemen yang dinilai baik oleh para konsumen serta memperbaiki yang kurang baik. Produk yang berkualitas berperan menciptakan keunggulan bersaing serta menciptakan keuntungan perusahaan.

Berdasarkan uraian dan penelitian terdahulu yang berkaitan dengan promosi, citra destinasi dan kualitas produk, maka penelitian ini dilakukan untuk menguji ketiga variabel tersebut pada variabel keunggulan bersaing. Adapun obyek penelitian adalah para pelaku UKM yang ada di Kampung Wisata Bisnis di Desa Tegalwaru, Kecamatan Ciampea, Kabupaten Bogor. Dalam penelitian ini, pertanyaan pokok yang diajukan adalah: Apakah promosi, citra destinasi dan kualitas produk berpengaruh positif dan signifikan terhadap keunggulan bersaing UMKM di Kampung Wisata Bisnis Tegalwaru?

Dengan pertanyaan pokok tersebut, maka kerangka konsep yang dikembangkan dalam penelitian ini adalah sebagaimana digambarkan pada Gambar 1.

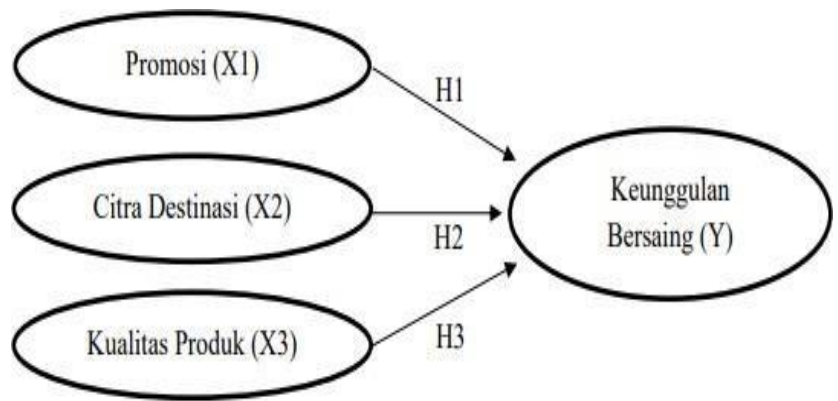

Gambar 1. Kerangka Konseptual Penelitian 
Melalui kerangka konseptual ini, maka hipotesis yang diajukan adalah sebagai berikut:

H1: Promosi berpengaruh positif dan signifikan terhadap keunggulan bersaing UMKM di Kampung Wisata Bisnis Tegalwaru.

H2: Citra Destinasi berpengaruh positif dan signifikan terhadap keunggulan bersaing UMKM di Kampung Wisata Bisnis Tegalwaru

H3: Kualitas Produk berpengaruh positif dan signifikan terhadap keunggulan bersaing UMKM di Kampung Wisata Bisnis Tegalwaru.

Tujuan dari penelitian ini untuk mengetahui dan menganalisis pengaruh Promosi, Citra Destinasi dan Kualitas Produk terhadap Keunggulan Bersaing UMKM di Kampung Wisata Bisnis Tegalwaru. Hasil dari penelitian ini diharapkan dapat memberikan manfaat sebagai bahan acuan Kementerian Pariwisata dan Pemerintah untuk mengambil kebijakan yang tepat untuk mempromosikan tempat wisata di Bogor, serta tempat wisata lain di Indonesia. Selain itu, penelitian ini diharapkan bisa berkontribusi bagi pendalaman pengetahuan dan bahan kajian untuk mengetahui pengaruh dari upaya pengembangan UMKM dalam memberikan kontribusi terhadap Citra Destinasi Wisata, Kampung Wisata Bisnis Tegal Waru, Bogor.

\section{METODE}

Penelitian ini menggunakan metode analisis kausal. Analisis kausal adalah hubungan yang bersifat sebab akibat. Penelitian yang dilakukan untuk mengetahui tentang pengaruh satu atau lebih variabel bebas (variabel independen) terhadap variabel terikat (variabel dependen). Variabel independen adalah variabel yang mempengaruhi atau yang menjadi sebab perubahan atau timbulnya variabel dependen (terikat). Variabel dependen adalah variabel yang dipengaruhi atau yang menjadi akibat karena adanya variabel bebas (Sugiyono, 2013). Tujuan penelitian kausal dalam hal ini adalah untuk mengetahui seberapa besar pengaruh promosi, citra destinasi, dan kualitas produk terhadap keunggulan bersaing UMKM di Kampung Wisata Bisnis Tegalwaru. Pendekatan yang dilakukan dalam penelitian ini adalah pendekatan kuantitatif.

Populasi penelitian adalah UMKM di Tegalwaru, dimana peneliti telah berkunjung ke Desa Wisata Bisnis Tegal dan diketahui dari Kelurahan Tegalwaru bahwa terdapat kurang lebih 256 UMKM yang berdomisili di 6 RW. Populasi adalah wilayah generalisasi yang terdiri atas objek atau subjek yang mempunyai kualitas atau karakteristik tertentu yang ditetapkan oleh peneliti untuk dipelajari dan kemudian ditarik kesimpulannya. Dapat disimpulkan populasi merupakan keseluruhan kelompok orang, peristiwa, atau hal yang ingin peneliti investigasi. Populasi juga dapat memudahkan peneliti dalam melakukan penelitiannya Sugiyono (2013).

Sampel adalah bagian dari jumlah dan karakteristik yang dimiliki oleh populasi. Bila populasi besar dan penelitian tidak mungkin mempelajari semua yang ada pada populasi, maka peneliti dapat menggunakan sampel yang diambil dari 
populasi. Apa yang dipelajari pada sampel itu, kesimpulannya akan dapat diberlakukan untuk populasi. Sehingga sampel yang diambil dari populasi harus representatif. Jika sampel yang dipilih tidak rerpresentatif, maka peneliti tidak mampu memilih sampel yang representatif, sehingga membuat kesimpulan yang salah tentang suatu penelitian (Sugiyono, 2013).

Alat analisis yang akan digunakan yaitu Parsial Least Square (PLS). Hair (2011) menyebutkan bahwa penentuan jumlah sampel minimum yang representative tergantung jumlah indikator dikali lima sampai sepuluh. Berdasarkan hal tersebut, jumlah indikator penelitian ini menggunakan 32 indikator, dikali lima maka jumlah sampel yang digunakan penelitian ini yaitu 160 responden. Teknik pengambilan sampel penelitian ini yaitu simple random sampling. Menurut Sugiyono (2017), simple random sampling adalah pengambilan anggota sampel dari populasi yang dilakukan secara acak tanpa memperhatikan strata yang ada dalam populasi itu.

Dengan demikian siapa saja dapat memberikan informasi baik secara tidak sengaja atau kebetulan bertemu dengan peneliti, dapat digunakan sebagai sampel, bila dilihat orang yang memberikan informasi tersebut cocok sebagai sumber data. Kriteria yang digunakan untuk penelitian ini adalah pengelola UMKM di Tegalwaru. Waktu penelitian dilakukan sejak bulan Mei 2019 sampai dengan September 2020. Penelitian bertempat di wilayah Bogor, Jawa Barat, subjek yang digunakan oleh peneliti adalah UMKM yang ada di wilayah Tegalwaru, Bogor.

\section{Pengumpulan Data}

Metode pengumpulan data penelitian menggunakan teknik kuesioner dengan memberi pertanyaan atau pernyataan tertulis kepada responden untuk dijawab. Peneliti mengajukan kuesioner yang berisi pernyataan kepada pengelola UMKM di Tegalwaru dan responden bisa menjawab dari beberapa pilihan jawaban yang disediakan peneliti. Sugiyono (2013) menyatakan bahwa kuesioner merupakan teknik pengumpulan data yang dilakukan dengan cara memberi seperangkat pertanyaan atau pernyataan tertulis kepada responden untuk dijawab. Pengumpulan data adalah langkah penting agar mendapatkan data valid dan kredibel. Teknik pengumpulan data merupakan angka yang paling utama dalam penelitian, karena tujuan utama dari penelitian adalah mendapatkan data.

\section{Analisis Data}

Metode analisis data yang digunakan adalah analisis deskriptif untuk penggambaran tentang statistik data, seperti: minimum, maximum, mean, sum, std deviation, variance, range, dan lain-lain. Menurut Sugiyono (2013) analisis deskriptif adalah statistik yang digunakan untuk menganalisis data dengan cara mendeskrpsikan atau menggambarkan data yang telah terkumpul sebagaimana adanya tanpa bermaksud membuat kesimpulan yang berlaku untuk 53 umum atau generalisasi. Adapun metode desktiptif adalah rumusan masalah yang berkenaan dengan pertanyaan terhadap keberadaan variabel, baik hanya pada satu variabel atau lebih. 
Pada penelitian ini, penulis membagi dua jenis deskripsi, yaitu deskripsi responden yang berisi mengenai identitas responden seperti: jenis UMKM responden, lama usaha responden, penghasilan responden, serta pendidikan responden. Deskripsi berikutnya berisi jawaban responden atas kuesioner yang telah disebar melalui google form dan dinyatakan dalam bentuk Skala Likert.

\section{HASIL DAN PEMBAHASAN}

Statistik deskriptif merupakan cara menggambarkan dan menyajikan informasi dari sejumlah besar data. Dengan statistik deskriptif data mentah diubah menjadi informasi yang menggambarkan fenomena atau karakteristik dari data.

\section{Deskriptif Responden}

- Deskriptif Karakteristik Responden Berdasarkan Jenis UMKM

Tabel 1. Karakteristik Responden Berdasarkan Jenis UMKM

\begin{tabular}{|l|c|c|c|}
\hline \multicolumn{1}{|c|}{ Jenis UMKM } & Frequency & Percent & $\begin{array}{c}\text { Cumulative } \\
\text { Percent }\end{array}$ \\
\hline UMKM Makanan/Minuman & 73 & 45,6 & 45,6 \\
\hline UMKM Peternakan & 46 & 28,7 & 74,4 \\
\hline UMKM Kerajinan & 19 & 11,9 & 86,3 \\
\hline Lainnya & 22 & 13,8 & 100,0 \\
\hline Total & 160 & 100,0 & 100,0 \\
\hline
\end{tabular}

Tabel 1 adalah statistik deskriptif hasil pengolahan karakteristik responden berdasarkan jenis UMKM. Hasil pengolahan data pada Tabel 1 menunjukan bahwa dari 160 responden terdapat 73 responden atau sebesar 45,6\% responden berjenis UMKM makanan/ minuman, sebanyak 46 responden atau sebesar 28,7\% responden berjenis UMKM peternakan, sebanyak 19 responden atau sebesar 11,9\% responden berjenis UMKM kerajinan dan sebanyak 22 responden atau sebesar $13,8 \%$ responden berjenis UMKM lainnya. Jadi, mayoritas responden dalam penelitian ini adalah responden berjenis UMKM makanan/ minuman.

- Deskriptif Responden Berdasarkan Lama Usaha UMKM

Tabel 2. Karakteristik Responden Berdasarkan Lama Usaha UMKM

\begin{tabular}{|c|c|c|c|}
\hline $\begin{array}{c}\text { Lama Usaha } \\
\text { UMKM }\end{array}$ & Frequency & Percent & Cumulative Percent \\
\hline$<1$ Tahun & 28 & 17,5 & 17,5 \\
\hline 2-5 Tahun & 44 & 27,5 & 45,0 \\
\hline 6-10 Tahun & 61 & 38,1 & 83,1 \\
\hline$>10$ Tahun & 27 & 16,9 & 100,0 \\
\hline Total & 160 & 100,0 & 100,0 \\
\hline
\end{tabular}


Tabel 2 adalah statistik deskriptif hasil pengolahan karakteristik responden berdasarkan lama usaha UMKM. Hasil pengolahan data pada Tabel 2 menunjukkan bahwa dari 160 responden yang memiliki jumlah tertinggi hingga terendah menurut urutannya adalah: Responden usia antara $<1$ tahun sebanyak 28 responden atau sebesar 17,5\%; Responden usia 2- 5 tahun sebanyak 44 responden atau sebesar 27,5\%; Responden usia antara 6-10 tahun sebanyak 61 responden atau sebesar $38,1 \%$, dan; Responden usia $\geq 10$ tahun sebanyak 27 responden atau sebesar 16,9\%. Jadi, mayoritas responden dalam penelitian ini adalah responden UMKM yang berusianya mencapai 6 sampai dengan 10 tahun.

- Deskriptif Karakteristik Responden Berdasarkan Jenjang dan Jenis Pendidikan Yang Pernah Diikuti

Tabel 3. Karakteristik Responden Berdasarkan Jenjang dan Jenis Pendidikan

\begin{tabular}{|l|c|c|c|}
\hline Pendidikan & Frequency & Percent & Cumulative Percent \\
\hline SMP/MTs & 13 & 8,1 & 8,1 \\
\hline SMA/Sederajat & 70 & 43,8 & 51,9 \\
\hline D3/D4/S1 & 51 & 31,9 & 83,8 \\
\hline Lain-lain & 26 & 16,3 & 100,0 \\
\hline Total & 160 & 100,0 & 100,0 \\
\hline
\end{tabular}

Tabel 3 adalah statistik deskriptif hasil pengolahan karakteristik responden berdasarkan jenjang dan jenis pendidikan yang pernah diikuti. Hasil pengolahan data pada Tabel 3 menunjukkan bahwa dari 160 responden terdapat 70 responden atau sebesar 43,8\% dari jenis pendidikan SMA atau Sederajat yang pernah diikuti; terdapat 51 responden atau sebesar 31,9\% dari jenis pendidikan D3/ D4/ S1 yang pernah diikuti; terdapat 13 responden atau sebesar $8,1 \%$ dari jenis pendidikan SMP/ MTs yang pernah diikuti, dan terdapat 26 responden atau sebesar 16,3\% dari jenis pendidikan lainnya yang pernah diikuti. Jadi, mayoritas responden dalam penelitian ini adalah dengan jenjang pendidikan SMA/Sederajat yang pernah diikuti.

- Deskriptif Karakteristik Responden Berdasarkan Penghasilan Per-Bulan

Tabel 4. Karakteristik Responden Berdasarkan Penghasilan Perbulan

\begin{tabular}{|l|c|c|c|}
\hline \multicolumn{1}{|c|}{ Penghasilan Perbulan } & Frequency & Percent & Cumulative Percent \\
\hline$<$ Rp 3.000.000 & 27 & 16,9 & 16,9 \\
\hline $\begin{array}{l}\text { Rp3.000.000- } \\
\text { Rp.5.000.000 }\end{array}$ & 77 & 48,1 & 65,0 \\
\hline $\begin{array}{l}\text { Rp5.000.000- } \\
\text { Rp10.000.000 }\end{array}$ & 40 & 25,0 & 90,0 \\
\hline
\end{tabular}




\begin{tabular}{|l|c|r|r|}
\hline$>$ Rp10.000.000 & 16 & 10,0 & 100,0 \\
\hline Total & 160 & 100,0 & 100,0 \\
\hline
\end{tabular}

Tabel 4 adalah statistik deskriptif hasil pengolahan karakteristik responden berdasarkan penghasilan per-bulan. Hasil pengolahan data pada Tabel 4 menunjukkan bahwa dari 160 responden terdapat 77 responden atau sebesar $48,1 \%$ dengan pendapatan sebesar Rp 1.000.000 - Rp 5.000.000; terdapat 40 responden atau sebesar 25,0\% dengan pendapatan sebesar Rp 5.000.000 - Rp 10.000.000; terdapat 27 responden atau sebesar 16,9\% dengan pendapatan sebesar $<\mathrm{Rp} 3.000 .000$; dan terdapat 16 responden atau sebesar $10 \%$ dengan pendapatan sebesar $>$ Rp 10.000.000. Jadi, mayoritas responden dalam penelitian ini adalah responden yang pendapatannya sebesar Rp 3.000.000 - Rp 5.000.000.

- Deskriptif Responden Berdasarkan Pekerjaan Sebelum Mendirikan UMKM Tabel 5. Karakteristik Responden Berdasarkan Pekerjaan Sebelum Mendirikan UMKM

\begin{tabular}{|l|c|c|c|}
\hline Sebelumnya & Frequency & Percent & Cumulative Percent \\
\hline TKI/TWK & 3 & 1,9 & 1,9 \\
\hline Petani & 73 & 45,6 & 47,5 \\
\hline Sopir & 8 & 5,0 & 52,5 \\
\hline Pedagang & 16 & 10,0 & 62,5 \\
\hline PNS & 37 & 23,1 & 85,6 \\
\hline Buruh/Kuli & 12 & 7,5 & 93,1 \\
\hline Lain- lain & 11 & 6,9 & 100,0 \\
\hline Total & 160 & 100,0 & 100,0 \\
\hline
\end{tabular}

Table 5 adalah statistik deskriptif hasil pengolahan karakteristik responden berdasarkan pekerjaan sebelum mendirikan UMKM. Hasil pengolahan data pada Tabel 5 menunjukkan bahwa dari 160 responden terdapat 73 responden atau sebesar $45,6 \%$ dengan pekerjaan sebelumnya petani; terdapat 37 responden atau sebesar $23,1 \%$ dengan pekerjaan sebelumnya PNS; terdapat 16 responden atau sebesar $10,0 \%$ dengan pekerjaan sebelumnya pedagang; terdapat 12 responden atau sebesar $7,5 \%$ dengan pekerjaan sebelumnya buruh/kuli; terdapat 8 responden atau sebesar $5 \%$ dengan pekerjaan sebelumnya sopir; terdapat 3 responden atau sebesar 1,9\% dengan pekerjaan sebelumnya TKI/TKW; dan terdapat 11 responden atau sebesar $6,9 \%$ dengan pekerjaan sebelumnya yaitu lainnya. Jadi, mayoritas responden dalam penelitian ini adalah responden yang pekerjaan sebelumnya adalah petani.

\section{Hasil Analisis Data Partial Least Square (PLS)}

Partial Least Square merupakan metode analisis Component/Variance Based Structural Equation Modeling dimana pengolahan datanya menggunakan program Partial Least Square (Smart-PLS) versi 3.0. PLS (Partial Least Square) 
sebagai model alternatif dari variance Based SEM. PLS dimaksudkan untuk cuasalpredictive analysis dalam situasi kompleksitas yang tinggi dan dukungan teori yang rendah (Ghozali, 2014).

PLS memiliki tujuan untuk mencari hubungan linear prediktif optimal yang ada pada data. Walaupun PLS dapat juga digunakan untuk mengkonfirmasi teori, tetapi dapat juga digunakan menjelaskan ada atau tidaknya hubungan antar variabel laten. Seperti dinyatakan oleh Ghozali (2014), Partial Least Square (PLS) merupakan metode analisis yang powerfull karena tidak didasarkan banyak asumsi, data tidak harus terdistribusi normal multivariate, dan sample tidak harus besar. Langkah-langkah pengujian yang dilakukan sebagai berikut:

\section{Evaluasi Uji Model Pengukuran (Outer Model)}

Analisa outer model dilakukan untuk memastikan bahwa pengukuran yang digunakan layak dijadikan pengukuran (valid dan reliable). Outer Model adalah model pengukuran yang terdiri dari indikator dan jalur yang menghubungkan mereka untuk faktor masing-masing. Analisa outer model dapat dilihat dari beberapa indikator berikut:

a) Convergent Validity

Pengujian Convergent Validity dari masing-masing indikator konstruk. Menurut Chin dalam Ghozali (2014), suatu indikator dikatakan mempunyai valid jika nilainya lebih besar dari 0,70 , sedangkan loading factor 0,50 sampai 0,60 dapat dianggap cukup. Berdasarkan kriteria ini bila ada loading faktor dibawah 0,50 maka akan di drop dari model.

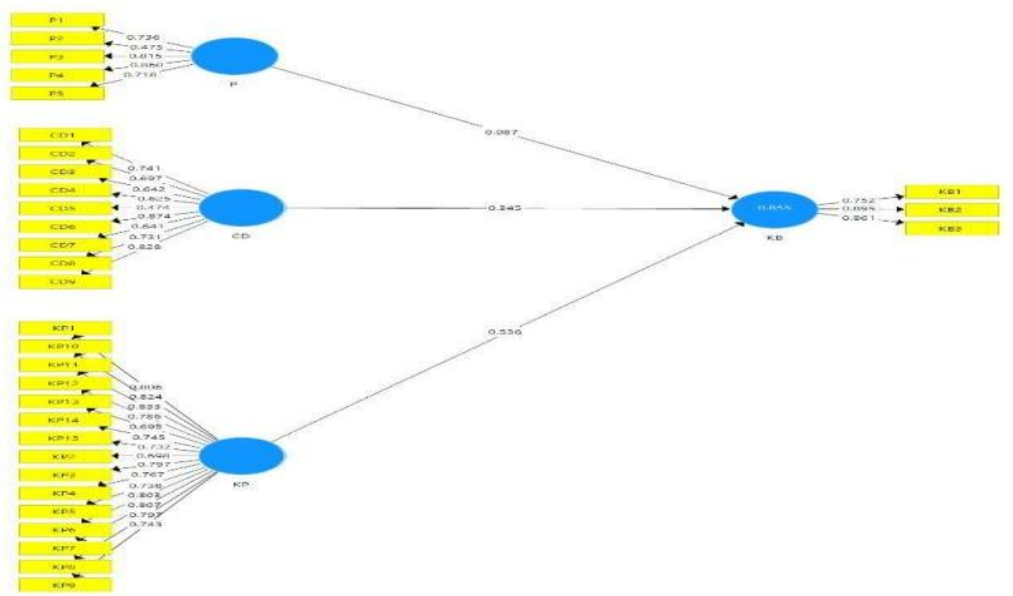

Gambar 2. Hasil Algoritma PLS, (Hasil Pengolahan PLS 3.0) 
Tabel 6. Hasil Pengujian Convergent Validity, (Hasil Pengolahan PLS 3.0)

\begin{tabular}{|c|c|c|c|}
\hline VARIABEL & INDIKATOR & $\begin{array}{c}\text { OUTER } \\
\text { LOADINGS }\end{array}$ & KETERANGAN \\
\hline \multirow{5}{*}{ PROMOSI } & P1.1 & 0.736 & VAIID \\
\hline & P1.2 & 0.475 & TIADK VALID \\
\hline & P1.3 & 0.815 & VALID \\
\hline & P1.4 & 0.860 & VAIID \\
\hline & P1.5 & 0.718 & VALID \\
\hline \multirow{9}{*}{ CITRA DESTINASI } & CD2.1 & 0.741 & VALID \\
\hline & $\mathrm{CD} 2.2$ & 0.697 & VALID \\
\hline & $\mathrm{CD}_{2.3}$ & 0.642 & VALID \\
\hline & $\mathrm{CD}_{2} .4$ & 0.625 & VALID \\
\hline & $\mathrm{CD}_{2} .5$ & 0.474 & TIADK VALID \\
\hline & CD2.6 & 0.874 & VAIID \\
\hline & CD 2.7 & 0.641 & VAIID \\
\hline & CD2.8 & 0.731 & VALID \\
\hline & CD2.9 & 0.828 & VAIID \\
\hline \multirow{15}{*}{$\begin{array}{l}\text { KUALITAS } \\
\text { PRODUK }\end{array}$} & KP3.1 & 0.806 & VALID \\
\hline & KP3.2 & 0.698 & VALID \\
\hline & KP3.3 & 0.797 & VAIID \\
\hline & KP3.4 & 0.767 & VALID \\
\hline & KP3.5 & 0.738 & VALID \\
\hline & KP3.6 & 0.803 & VALID \\
\hline & KP3.7 & 0.807 & VAIID \\
\hline & KP3.8 & 0.797 & VALID \\
\hline & KP3.9 & 0.743 & VAIID \\
\hline & KP3.10 & 0.824 & VALID \\
\hline & KP3.11 & 0.833 & VAIID \\
\hline & KP3.12 & 0.786 & VALID \\
\hline & KP3.13 & 0.695 & VAIID \\
\hline & KP3.14 & 0.745 & VALID \\
\hline & KP3.15 & 0.732 & VALID \\
\hline \multirow{3}{*}{$\begin{array}{c}\text { KEUNGGULAN } \\
\text { BERSAING }\end{array}$} & KB1.1 & 0.752 & VALID \\
\hline & KB1.2 & 0.895 & VAIID \\
\hline & KB1.3 & 0.861 & VAIID \\
\hline
\end{tabular}

Hasil Algoritma PLS pada Gambar 2 dan Hasil Pengujian Convergent Validity Tabel 6, menunjukkan bahwa indikator P2 dan CD5 memiliki nilai loading factor yang paling rendah diantara loading factor yang lain dan nilai AVE pada variabel Promosi. Hal ini disebabkan karena nilai AVE pada variabel Promosi di bawah 0,5 maka dinyatakan tidak valid dan tidak signifikan. Re-estimasi atau melakukan estimasi ulang untuk evaluasi model pengukuran dimaksudkan untuk memeriksa kembali validitas loading factor setiap indikatornya.

Jika uji validitas dengan outer loadings telah terpenuhi, maka model pengukuran mempunyai potensi untuk diuji lebih lanjut. Oleh karena itu indikator P2 dan CD5 yang mempunyai nilai loading factor terendah akan dihilangkan dari model.

Hasil dari penghilangan indikator dan perhitungan kembali bisa dilihat pada Gambar 3 dan Tabel 7. 


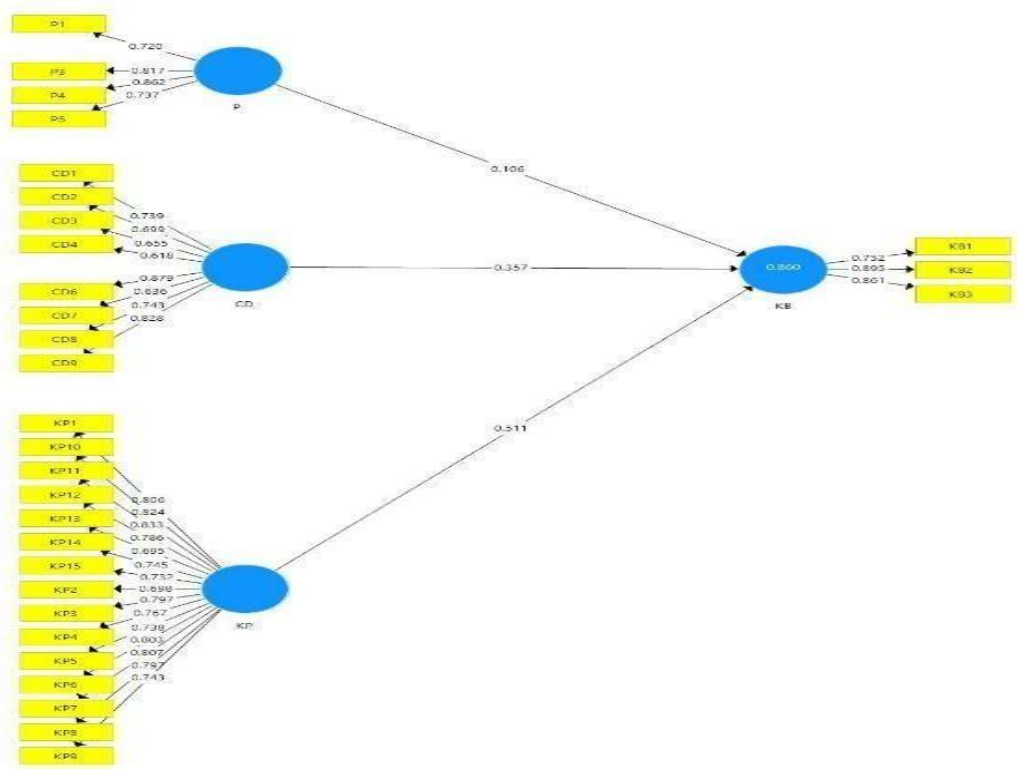

Gambar 3. Hasil Algoritma PLS (Modifikasi), (Hasil Pengolahan PLS 3.0)

Tabel 7. Hasil Pengujian Convergent Validity (Modifikasi), (Hasil Pengolahan PLS 3.0).

\begin{tabular}{|c|c|c|c|}
\hline VARIABEL & INDHKATOR & $\begin{array}{l}\text { OUTER } \\
\text { LOADINGS }\end{array}$ & KETERANGAN \\
\hline \multirow{4}{*}{ PROMOSI } & P1.1 & 0.720 & VAIID \\
\hline & P1.3 & 0.817 & VAIID \\
\hline & P1.4 & 0.862 & VAIID \\
\hline & P1.5 & 0.737 & VAIID \\
\hline \multirow{8}{*}{$\begin{array}{l}\text { CITRA } \\
\text { DESTINASI }\end{array}$} & CD2.1 & 0.739 & VAIID \\
\hline & CD2.2 & 0.699 & VAIID \\
\hline & CD 2.3 & 0.655 & VAIID \\
\hline & CD 2.4 & 0.618 & VAIID \\
\hline & CD 2.6 & 0.879 & VAIID \\
\hline & CD2.7 & 0.636 & VAIIID \\
\hline & CD2.8 & 0.743 & VAIIID \\
\hline & CD2.9 & 0.828 & VAIID \\
\hline \multirow{15}{*}{$\begin{array}{l}\text { KUAIITAS } \\
\text { PRODUK }\end{array}$} & KP3 3 1 & 0.806 & VAIID \\
\hline & KP3.2 & 0.698 & VAIID \\
\hline & KP 333 & 0.797 & VAIID \\
\hline & KP3_4 & 0.767 & VAIID \\
\hline & KP3.5 & 0.738 & VAIID \\
\hline & KP3.6 & 0.803 & VAIID \\
\hline & KP 3.7 & 0.807 & VAIID \\
\hline & KP3.8 & 0.797 & VAIID \\
\hline & KP339 & 0.743 & VAIID \\
\hline & KP3.10 & 0.824 & VAIID \\
\hline & KP3.11 & 0.833 & VAIID \\
\hline & KP3.12 & 0.786 & VAIID \\
\hline & KP3.13 & 0.695 & VAIID \\
\hline & KPP3.14 & 0.745 & VAIID \\
\hline & KP3.15 & 0.732 & VAIID \\
\hline \multirow{3}{*}{$\begin{array}{l}\text { KEUNGGUIAAN } \\
\text { BERSAING }\end{array}$} & KB1.1 & 0.752 & VAIID \\
\hline & KB1.2 & 0.895 & VAIID \\
\hline & $\mathrm{K} B 1.3$ & 0.861 & VAIIID \\
\hline
\end{tabular}

Hasil dari modifikasi pengujian convergent validity pada Gambar 3 dan Tabel 7 menunjukkan bahwa semua indikator telah memenuhi convergent validity karena memiliki nilai loading factor di atas 0,50 . 
b) Average Variance Extracted (AVE)

Nilai AVE bertujuan untuk mengukur tingkat variansi suatu komponen konstruk yang dihimpun dari indikatornya dengan menyesuaikan pada tingkat kesalahan. Pengujian dengan nilai AVE bersifat lebih kritis dari pada composite reliability. Nilai Ave minimal yang direkomendasikan adalah 0,50 .

Tabel 8. Hasil Uji Average Variance Extracted (AVE)

\begin{tabular}{|l|c|}
\hline \multicolumn{1}{|c|}{ Variabel } & Average Variance Extracted (AVE) \\
\hline Promosi & $\mathbf{0 , 6 1 8}$ \\
\hline Citra Destinasi & $\mathbf{0 , 5 3 3}$ \\
\hline Kualitas Produk & $\mathbf{0 , 5 9 7}$ \\
\hline $\begin{array}{l}\text { Keunggulan } \\
\text { Bersaing }\end{array}$ & $\mathbf{0 , 7 0 3}$ \\
\hline
\end{tabular}

Hasil uji nilai average variance extracted (AVE) pada Tabel 8 menunjukkan bahwa seluruh konstruk mempunyai reliabilitas yang potensial untuk diuji lebih lanjut. Hal ini dikarenakan nilai average variance extracted (AVE) pada seluruh konstruk telah lebih besar dari 0,50.

c) Composite Reliability dan Cronbach's Alpha

Untuk memastikan bahwa tidak ada masalah terkait pengukuran maka langkah terakhir dalam evaluasi outer model adalah menguji uji reliabitas dari model. Uji reliabilitas dilakukan dengan menggunakan indikator Composite Reliability dan Cronbach's Alpha. Pengujian Composite Reliability dan Cronbach's Alpha bertujuan untuk menguji reliabilitas instrumen dalam suatu model penelitian. Atau mengukur internal consistency dan nilainya harus di atas 0,60. Apabila seluruh nilai variabel laten memiliki nilai Composite Reliability maupun Cronbach's Alpha $\geq 0,70$ hal itu berarti konstruk memiliki reabilitas yang baik atau kuesioner yang digunakan sebagai alat dalam penelitian ini telah andal atau konsisten.

Tabel 9. Hasil Pengujian Composite Reliability dan Cronbach's Alpha

\begin{tabular}{|l|c|c|c|}
\hline Variabel & $\begin{array}{c}\text { Composite } \\
\text { Reliability }\end{array}$ & $\begin{array}{c}\text { Cronbach's } \\
\text { Alpha }\end{array}$ & Keterangan \\
\hline Promosi & 0,865 & 0,794 & Reliable \\
\hline Citra Destinasi & 0,900 & 0,872 & Reliable \\
\hline Kualitas Produk & 0,957 & 0,951 & Reliable \\
\hline Keunggulan Bersaing & 0,876 & 0,787 & Reliable \\
\hline
\end{tabular}


Hasil pengujian composite reliability dan cronbach's alpha pada Tabel 9 menunjukkan nilai yang memuaskan, yaitu semua variabel laten telah reliabel karena seluruh nilai variabel laten memiliki nilai composite reliability dan cronbach's alpha $\geq 0,70$. Jadi dapat disimpulkan bahwa, kuesioner yang digunakan sebagai alat penelitian ini telah andal atau konsisten.

\section{Pengujian Uji Model Struktural (Inner Model)}

Setelah model yang diestimasi memenuhi kriteria Outer Model, berikutnya dilakukan pengujian model struktural (Inner Model). Pengujian inner model adalah pengembangan model berbasis konsep dan teori dalam rangka menganalisis hubungan antara variabel eksogen dan endogen yang telah dijabarkan dalam rerangka konseptual. Tahapan pengujian terhadap model struktural (inner model) dilakukan dengan langkah-langkah berikut ini:

- $\quad$ Nilai R-Square $\left(\mathrm{R}^{2}\right)$ Tabel 10 .

Nilai R-square yang merupakan uji goodness of fit model bisa dilihat pada

Tabel 10. Hasil Uji Nilai R-Square $\left(\mathrm{R}^{2}\right)$

\begin{tabular}{|l|c|}
\hline \multicolumn{1}{|c|}{ Variabel } & R-Square $\left(\mathbf{R}^{\mathbf{2}}\right)$ \\
\hline $\begin{array}{l}\text { Keunggulan } \\
\text { Bersaing }\end{array}$ & 0,860 \\
\hline
\end{tabular}

Data pada Tabel 10 dapat disimpulkan bahwa nilai R-Square sebesar 0,860, yang berarti variabilitas Keunggulan Bersaing yang dapat dijelaskan oleh ketiga variabel independen dalam model yaitu Promosi, Citra Destinasi, dan Kualitas Produk sebesar $86,0 \%$ dan sisanya $(100-86,0)$ 14,0\% dijelaskan oleh variabel lain yang tidak diteliti dalam model ini.

\section{Pengaruh Promosi Terhadap Keunggulan Bersaing}

Berdasarkan uji hipotesis pertama (H1) pada penelitian ini, diperoleh hasil bahwa Promosi memiliki pengaruh positif signifikan terhadap Keunggulan Bersaing, dimana nilai Original Sample sebesar 0,106 dan nilai T Statistik > T tabel $(2,293>$ 1,96) dan hipotesis 1 dalam hal ini diterima. Artinya, Promosi terbukti mempengaruhi Keunggulan Bersaing UMKM di Tegalwaru.

\section{Pengaruh Citra Destinasi Terhadap Keunggulan Bersaing}

Berdasarkan uji hipotesis kedua $(\mathrm{H} 2)$ pada penelitian ini, menunjukkan hasil bahwa Citra Destinasi terdapat pengaruh positif signifikan terhadap Keunggulan Bersaing karena, nilai Original Sample sebesar 0,357 dan nilai T Statistik > T tabel $(5,357>1,96)$ dan hipotesis 2 dalam hal ini diterima, artinya Citra Destinasi terbukti 
mempengaruhi Keunggulan Bersaing UMKM di Tegalwaru. Hasil Penelitian ini diperkuat oleh penelitian sebelumnya oleh Rani (2019) bahwa citra perusahaan berpengaruh positif dan signifikan terhadap keunggulan bersaing pada (Studi Kasus Pada Bank Syariah Mandiri KC Bandung Buah Batu).

\section{Pengaruh Kualitas Produk Terhadap Keunggulan Bersaing}

Berdasarkan uji hipotesis ketiga (H3) pada penelitian ini, menunjukkan hasil bahwa Kualitas Produk terdapat pengaruh positif signifikan terhadap Keunggulan Bersaing karena, nilai Original Sample sebesar 0,511 dan nilai T Statistik > T tabel $(6,836>1,96)$ dan hipotesis 3 dalam hal ini diterima, artinya Kualitas Produk terbukti mempengaruhi dengan Keunggulan Bersaing UMKM Tegalwaru.

\section{SIMPULAN DAN SARAN}

Penelitian ini dimaksudkan untuk mengetahui faktor yang mempengaruhi Keunggulan Bersaing UMKM di Tegalwaru, dengan melakukan analisis terhadap variabel Promosi, Citra Destinasi, dan Kualitas Produk. Berdasarkan analisis data dan pembahasan yang dikemukakan, maka dapat dikemukakan kesimpulan bahwa, Promosi berpengaruh positif dan signifikan terhadap Keunggulan Bersaing; Citra Destinasi berpengaruh positif dan signifikan terhadap Keunggulan Bersaing, dan; Kualitas Produk berpengaruh positif dan signifikan terhadap Keunggulan Bersaing.

Berdasarkan hasil penelitian tersebut, maka peneliti memberikan saran kepada berbagai pihak yang akan menggunakan hasil penelitian ini di masa mendatang, yaiatu: pada variabel Promosi hampir di setiap indikator, mayoritas responden setuju bahwa promosi dapat meningkatkan penjualan produknya. Di sisi lain nilai jawaban responden yang paling kecil adalah indikator ke-lima dengan index rata-rata 2,79 yaitu "Penawaran produk UMKM membuat anda tertarik untuk mengenai lebih lanjut produk UMKM tersebut", yang artinya adalah sebagian responden merasa bahwa UMKM Tegalwaru kurang dalam memanfaatkan penawaran produk UMKM kepada pelanggannya. Oleh karena itu saran yang bisa dijadikan pertimbangan oleh UMKM di Tegalwaru adalah Promosi harus dilakukan oleh setiap pelaku usaha UMKM agar dapat meningkatkan penawaran yang lebih menarik perhatian kepada konsumen agar para konsumen tahu promosi yang diberikan oleh UMKM Tegalwaru.

Pada variabel Citra Destinasi hampir di setiap indikator, mayoritas setuju bahwa UMKM Tegalwaru memiliki citra yang baik. Di sisi lain bahwa jawaban responden yang paling kecil adalah indikator ke-lima dengan index rata-rata 2,75 yaitu "Aktivitas rekreasi keluarga yang sangat tersedia". Artinya sebagian responden merasa bahwa UMKM Tegalwaru tidak memberikan aktivitas rekreasi keluarga yang baik kepada konsumennya. Saran yang dapat dijadikan pertimbangan UMKM Tegalwaru yaitu memberikan kesan dan pesan positif terhadap aktivitas rekreasi keluarga di Kampung Wisata Bisnis Tegalwaru, sehingga membuat para konsumennya merasa nyaman ketika berada di Kampung Wisata Bisnis Tegalwaru.

Pada variabel Kualitas Produk hampir di setiap indikator mayoritas 
responden setuju bahwa UMKM di Tegalwaru memiliki kualitas produk yang sangat baik serta mampu membuat kepuasaan atas produk yang dihasilkan terhadap konsumennya. Di sisi lain jawaban responden yang paling kecil adalah indikator kelima dengan index rata-rata 2,69 yaitu "Saya merasa produk UMKM Kampung Wisata Bisnis Tegalwaru lebih baik dibandingkan yang lain”. Artinya sebagian responden merasa kurang puas dengan produk yang diberikan UMKM Tegalwaru. Oleh karena itu saran yang untuk dijadikan pertimbangan oleh UMKM Tegalwaru adalah agar dapat memberikan kualitas produk yang baik kepada konsumennya dan bahwa yang dilakukan UMKM Tegalwaru selalu memberikan kepuasaan dan kenyamanan kepada para konsumennya.

Saran untuk penelitian selanjutnya, dilihat dari hasil uji $R$-Square menunjukkan bahwa Keunggulan Bersaing memperoleh 0,860 yang artinya variabel Promosi, Citra Destinasi dan Kualitas Produk memiliki pengaruh sebesar 86,0\%. Pada penelitian selanjutnya, disarankan agar dapat mengembangkan area penelitian dengan karakteristik yang berbeda sehingga penelitian lebih akurat, dan meneliti variabel lain yang tidak diteliti dalam penelitian seperti: Kualitas Pelayanan, EWom, Harga, dan Kenyamanan. Penelitian selanjutnya disarakan bisa lebih teliti dalam melihat masalah serta jeli dalam menentukan variabel yang akan diteliti.

\section{DAFTAR PUSTAKA}

Anggraeni R. (2013) "Pengaruh Struktur Kepemilikan Manajerial, Ukuran Perusahaan, dan Praktik Corporate Governance Terhadap Manajemen Laba" Jurnal Ekonomi \& Bisnis, Vol. 2, No. 3, Tahun 2013.

Arbawa, Lexi dan Wardoyo. "Keunggulan Bersaing : Berpengaruh terhadap Kinerja Pemasaran (Studi pada UMKM Makanan dna Minuman di Kabupaten Kendal)". Jurnal Program Studi Magister Manajemen. Universitas Semarang. ISSN : 1979-4800 (cetak), ISSN : 2580-8451 (online).

Echtner, C.M. (2003) The Meaning and Measurement of Destination Image, The Journal of Tourism of Tourism Studies, 2(2),pp.

Ghozali, Imam. 2012. Aplikasi Analisis Multivariate dengan Program IBM SPSS. Yogyakarta: Universitas Diponegoro.

Hair, Jr., Joseph F., et. al. (2011). Multivariate Data Analysis. Fifth Edition.

New Jersey: Prentice Hall, Inc.

Kotler, Philip and Gary Armstrong. 2012. Prinsip-prinsip Pemasaran. Edisi 13. Jilid 1. Jakarta:Erlangga.

Kotler, $\mathrm{P}$ and $\mathrm{K}$ Keller. 2012. Marketing Management, $14^{\text {th }}$ Edition, Pearson 
Education, Inc., publishing as Prentice Hall, One Lake Street, Upper Saddle River, New Jersey 07458.

Kotler,P., Jhon Bowen and James Makens. 1996. Marketing for Hospitality and Tourism. USA: Prentice-Hall Inc.

Ni Putu Diah. (2017). Pengaruh Strategi Diferensiasi Terhadap Upaya Membangun Keunggulan Bersaing Pada Hotel Alila Ubud. E-Jurnal Manajemen Unud, Vol. 6, No. 11, 2017: 6120-6140.

Noviani, Rani (2019) Pengaruh Kualitas Pelayanan dan Citra Perusahaan Terhadap Keunggulan Bersaing Dengan Loyalitas Nasabah Sebagai Variabel Intervening (Studi Kasus Pada Bank Syariah Mandiri KC Bandung Buah Batu).

Novi, Ani (2020) Pengaruh Inovasi Produk, Kreatifitas Produk, dan Kualitas Produk Terhadap Keunggulan Bersaing (Studi Kasus Pada Kerajinan Tikar Eceng Gondok "Liar"). Vol 2 No 01 (2020) Jurnal Manajemen dan Bisnis Banten Jaya.

Osmanovic, J., Kenjic, V. and Zrnic, R. (2010). Destination Management: Concensus for Competitiveness. Tourism \& Hospitality Management Organization Conference Prosidings, pp. 513-525.

Sugiyono. (2013). Metode Penelitian Pendidikan Pendekatan Kuantitatif, Kualitatif, dan $R \& D$. Bandung: Alfabeta.

Sugiyono. (2017). Metode Penelitian Kuantitatif, Kualitatif, dan R\&D. Bandung : Alfabeta, $\mathrm{CV}$

Tjiptono, Fandy. (2012). Pemasaran Strajegik. Yogyakarta: ANDI.

Utama, I Gusti Bagus Rai. (2016). Pemasaran Pariwisata, Ed.1 ANDI, IKAPI, Jogjakarta.

Wardoyo dan Veronica, T. R. (2013). Pengaruh Good Corporate Governace, Corporate Social Responsibility \& Kinerja Keuangan Terhadap Nilai Perusahaan. Jurnal Dinamika Manajemen. Vol. 4, No 2, pp:132-149 